\title{
Effects of different priming treatments and priming durations on germination percentage of parsley (Petroselinum crispum L.) seeds
}

\author{
Atilla Dursun*, Melek Ekinci \\ Atatürk University, Agriculture Faculty, Department of Horticulture, Erzurum, Turkey; *Corresponding Author: atilladursun@,hotmail.com
}

Received 16 March 2010; revised 15 April 2010; accepted 20 April 2010.

\begin{abstract}
The effects of different priming treatments and priming durations on germination percentage at different temperatures in parsley seeds were studied. The seeds were treated for 2, 4, 6 and 8 days with the PEG 6000 ( $-0.5 \mathrm{MPa},-1.0 \mathrm{MPa}$ and $-1.5 \mathrm{MPa}), \mathrm{KNO}_{3}(0.30 \mathrm{~mol} / \mathrm{L}$ and $0.35 \mathrm{~mol} / \mathrm{L})$, Mannitol ( $0.50 \mathrm{~mol} / \mathrm{L}$ and $0.60 \mathrm{~mol} / \mathrm{L})$ and hydropriming (12h, 24h, 36h and $48 \mathrm{~h})$ and unprimed (control). Germination studies were made at $5,10,15,20$ and $25^{\circ} \mathrm{C}$. Percentage of germination at different temperatures was significantly affected by priming treatments. Hydropriming (12h, 24h and $36 \mathrm{~h}$ ) and mannitol $0.60 \mathrm{~mol} / \mathrm{L}$ at 2 day generally had the highest germination percentages. In general, the highest germination percentage with priming was determined at $10^{\circ} \mathrm{C}$. It may be said that seed priming treatments increased seed germination percentage at both low and high temperatures. The highest germination percentages were observed in both hydropriming and mannitol treatments as compared with PEG and $\mathrm{KNO}_{3}$ treatments. The PEG and $\mathrm{KNO}_{3}(2$ and 4 days) treatments were better than unprimed treatment in all of the temperatures.
\end{abstract}

Keywords: Parsley; Germination Percentage; Seed Priming; PEG; $\mathrm{KNO}_{3}$; Hydropriming

\section{INTRODUCTION}

Vegetables are important for human nutrition and its importance is getting increase in all around of the world. Good and high crop establishment is one of the major challenges to crop production in the world and its importance is recognized by farmers as well as researchers $[1,2]$. Constraints to good crop establishment include poor seedbed preparation, low quality seed, untimely seed sowing, and adverse weather conditions after sow- ing $[2,3]$. To improve vegetable stand establishment, priming techniques including osmopriming, solid matrix priming and hydropriming can be used. Seed priming is a pre-sowing physiological seed enhancement treatment involving the controlled hydration of seeds. Hydration is sufficient to allow pregerminative metabolic activation to take place, but insufficient to allow radicle protrusion through the seed coat [4]. This technique has been used in some vegetable seeds to increase the seed vigor, the germination speed, total germination rate and seedling uniformity, mainly under unfavorable environmental conditions. The technique can lead to better crop stands and higher crop yields $[5,6]$.

Seed germination and emergence of parsley growing period especially in early spring, summer and late autumn are critical. Parsley is one of the most important vegetable that seed germination has taken long time and it is difficult to be germinated it especially under unfavorable environmental conditions [7]. The germination percentage of parsley seed is lower than $55-75 \%$ in these kinds of conditions [8]. Thus, slow emergence and low emergence rate lead to smaller seedlings [9]. However, uniformity and rapidity of seed germination and emergence are essential to increase yield, quality and profits in crops $[9,10]$. For this reason, seed priming techniques have recently been used for many plant species to increase crop stands and higher yields [11]. Also, it is reported that seed priming is a suitable method of shortening the time to early crops and obtain flexibility in processing plant schedules [12].

The aim of this study was to determine the effects of different priming treatments and durations on germination percentage of parsley seeds.

\section{MATERIALS AND METHODS}

The experiment was carried out at the Horticultural Research Laboratory at the Agricultural Faculty of Ataturk University. D'Giant İtaliana parsley seeds were treated at 
2, 4, 6 and 8 day with PEG $6000(-0.5 \mathrm{MPa},-1.0 \mathrm{MPa}$ and $-1.5 \mathrm{MPa}), \mathrm{KNO}_{3}(0.30 \mathrm{~mol} / \mathrm{L}$ and $0.35 \mathrm{~mol} / \mathrm{L})$, mannitol $(050 \mathrm{~mol} / \mathrm{L}$ and $0.60 \mathrm{~mol} / \mathrm{L})$ and hydropriming (12h, 24h, 36h and 48h) and non primed (control). The experiment was conducted in growth cabinet at five temperatures $\left(5,10,15,20,25^{\circ} \mathrm{C}\right)$ with four replicates of 25 seeds placed on two sheets of filter paper and with deionized water. The number of germinated seeds was recorded and removed daily. The experiment was made based on a completely randomized design. All data were subjected to a one-way analysis of variance (ANOVA) and separated by $\mathrm{LSD}_{0.05}$.

\section{RESULTS}

Seed germination was significantly affected by priming treatments at different temperatures (Table 1, Figures 1 -5). Hydropriming (12 h, $24 \mathrm{~h}$ and $36 \mathrm{~h}$ ) and mannitol
$0.60 \mathrm{~mol} / \mathrm{L}$ at 2 day had generally the highest germination percentages. In general, the highest seed germination percentage with priming was determined at $10^{\circ} \mathrm{C}$ (Table 1, Figure 2). If temperatures were separately evaluated, it could be seen that the highest seed germination percentage was obtained from hydropriming $(12 \mathrm{~h}$, $24 \mathrm{~h}$ and $36 \mathrm{~h}$ ) and mannitol $0.60 \mathrm{~mol} / \mathrm{L}$ at 2 day at $5^{\circ} \mathrm{C}$ (Table 1, Figure 1); from hydropriming (12h and $24 \mathrm{~h})$, mannitol $0.60 \mathrm{~mol} / \mathrm{L}$ at 2 day and $-1.5 \mathrm{MPa}$ PEG / 2 day at $10^{\circ} \mathrm{C}$ (Table 1, Figure 2); from hydropriming (48 h) and mannitol $0.50 \mathrm{~mol} / \mathrm{L} \mathrm{(2} \mathrm{day)} \mathrm{and} 0.60 \mathrm{~mol} / \mathrm{L}$ (2 day) at $15^{\circ} \mathrm{C}$ (Table 1, Figure 3); from hydropriming (24 h), $-1.0 \mathrm{MPa}$ PEG / 4 day and -1.5 MPa PEG / 2 day at $20^{\circ} \mathrm{C}$ (Table 1, Figure 4); from hydropriming ( $24 \mathrm{~h}$ and $48 \mathrm{~h}$ ) at $25^{\circ} \mathrm{C}$ (Table 1, Figure 5). It was determined that seed priming treatments increased seed germination percentage at both low and high temperatures in the presented study.

Table 1. Effect of seed priming on germination percentage of parsley at different temperatures (\%).

\begin{tabular}{|c|c|c|c|c|c|c|}
\hline \multirow{2}{*}{ Applications } & \multicolumn{6}{|c|}{ Temperatures } \\
\hline & $5^{\circ} \mathrm{C}$ & $10^{\circ} \mathrm{C}$ & $15^{\circ} \mathrm{C}$ & $20^{\circ} \mathrm{C}$ & $25^{\circ} \mathrm{C}$ & Mean \\
\hline Control & $30.75 \mathrm{klm} * * *$ & 69.25 fgh $* * *$ & 77.25 a-d $* * *$ & $28.00 \mathrm{i} * * *$ & $49.25 \mathrm{~g} * * *$ & $50.90 \mathrm{jkl} * * *$ \\
\hline Hydropriming $12 \mathrm{~h}$ & $88.00 \mathrm{a}$ & $90.00 \mathrm{a}$ & $78.00 \mathrm{abc}$ & $61.25 \mathrm{abc}$ & $63.00 \mathrm{def}$ & $76.05 \mathrm{a}$ \\
\hline $24 \mathrm{~h}$ & $73.50 \mathrm{~cd}$ & $83.25 \mathrm{a}-\mathrm{d}$ & $74.75 \mathrm{a}-\mathrm{e}$ & $69.25 \mathrm{a}$ & $77.25 \mathrm{a}$ & $75.60 \mathrm{a}$ \\
\hline $32 \mathrm{~h}$ & $84.00 \mathrm{ab}$ & $81.25 \mathrm{bcd}$ & $80.00 \mathrm{ab}$ & $62.75 \mathrm{abc}$ & $69.25 \mathrm{bcd}$ & $75.45 \mathrm{a}$ \\
\hline $48 \mathrm{~h}$ & $65.50 \mathrm{ef}$ & $76.00 \mathrm{def}$ & $82.50 \mathrm{a}$ & $53.00 \mathrm{de}$ & $77.25 \mathrm{a}$ & $70.85 \mathrm{bc}$ \\
\hline$-0.5 \mathrm{MPa}$ PEG 2 day & $60.00 \mathrm{fg}$ & 77.25 cde & $69.50 \mathrm{c}-\mathrm{g}$ & $64.00 \mathrm{abc}$ & $72.00 \mathrm{abc}$ & 68.55 cde \\
\hline 4 day & $32.00 \mathrm{kl}$ & $63.25 \mathrm{~h}$ & $45.25 \mathrm{~lm}$ & $61.25 \mathrm{abc}$ & $61.25 \mathrm{ef}$ & $52.60 \mathrm{ijk}$ \\
\hline 6 day & 21.00 nop & $65.25 \mathrm{gh}$ & $56.00 \mathrm{jk}$ & 46.75 ef & $65.25 \mathrm{cde}$ & $50.85 \mathrm{jkl}$ \\
\hline 8 day & $9.50 \mathrm{q}$ & $40.00 \mathrm{j}$ & $26.00 \mathrm{o}$ & $37.00 \mathrm{gh}$ & $45.25 \mathrm{gh}$ & $31.55 \mathrm{o}$ \\
\hline$-1.0 \mathrm{MPa}$ PEG 2 day & $59.00 \mathrm{fg}$ & $80.75 \mathrm{bcd}$ & $73.25 \mathrm{~b}-\mathrm{f}$ & $63.00 \mathrm{abc}$ & $71.00 \mathrm{abc}$ & $69.4 \mathrm{bcd}$ \\
\hline 4 day & 46.75 hij & $70.75 \mathrm{e}-\mathrm{h}$ & $60.00 \mathrm{~h}-\mathrm{k}$ & $66.00 \mathrm{a}$ & $68.50 \mathrm{bcd}$ & $62.40 \mathrm{~h}$ \\
\hline 6 day & $28.00 \mathrm{k}-\mathrm{n}$ & $54.75 \mathrm{i}$ & $53.00 \mathrm{kl}$ & $41.00 \mathrm{fgh}$ & $61.50 \mathrm{ef}$ & $47.65 \mathrm{~lm}$ \\
\hline 8 day & $28.00 \mathrm{k}-\mathrm{n}$ & $39.00 \mathrm{j}$ & 30.00 no & $36.00 \mathrm{~h}$ & $40.00 \mathrm{~h}$ & $34.60 \mathrm{n}$ \\
\hline$-1.5 \mathrm{MPa}$ PEG 2 day & $62.75 \mathrm{ef}$ & $84.00 \mathrm{abc}$ & $73.00 \mathrm{~b}-\mathrm{f}$ & $68.00 \mathrm{a}$ & $72.00 \mathrm{abc}$ & $71.95 \mathrm{~b}$ \\
\hline 4 day & 48.00 hij & $65.50 \mathrm{gh}$ & $69.00 \mathrm{~d}-\mathrm{h}$ & $63.00 \mathrm{abc}$ & $73.00 \mathrm{ab}$ & $63.7 \mathrm{gh}$ \\
\hline 6 day & $33.25 \mathrm{k}$ & $68.00 \mathrm{gh}$ & $46.50 \mathrm{~lm}$ & $52.00 \mathrm{de}$ & $70.50 \mathrm{abc}$ & $54.05 \mathrm{ij}$ \\
\hline 8 day & $25.001-0$ & $46.00 \mathrm{j}$ & 31.00 no & $38.00 \mathrm{gh}$ & $42.00 \mathrm{~h}$ & $36.4 \mathrm{n}$ \\
\hline $\mathrm{KNO}_{3} 0.30 \mathrm{~mol} / 12$ day & 65.00 ef & $68.00 \mathrm{gh}$ & $63.00 \mathrm{~g}-\mathrm{j}$ & $65.25 \mathrm{ab}$ & $63.00 \mathrm{def}$ & $64.85 \mathrm{fgh}$ \\
\hline 4 day & $43.25 \mathrm{ij}$ & 70.00 e-h & $62.75 \mathrm{~g}-\mathrm{j}$ & $41.00 \mathrm{fgh}$ & $51.50 \mathrm{~g}$ & $53.80 \mathrm{ij}$ \\
\hline 6 day & $23.50 \mathrm{mno}$ & $44.00 \mathrm{j}$ & $46.00 \mathrm{~lm}$ & $48.00 \mathrm{ef}$ & $65.25 \mathrm{cde}$ & $45.35 \mathrm{~m}$ \\
\hline 8 day & $30.00 \mathrm{klm}$ & $43.00 \mathrm{j}$ & $34.75 \mathrm{n}$ & $23.25 \mathrm{i}$ & $22.00 \mathrm{j}$ & 30.60 op \\
\hline $\mathrm{KNO}_{3} 0.35 \mathrm{~mol} / 12$ day & $66.75 \mathrm{def}$ & $65.50 \mathrm{gh}$ & $64.50 \mathrm{f}-\mathrm{j}$ & $63.00 \mathrm{abc}$ & $70.75 \mathrm{abc}$ & $66.10 \mathrm{~d}-\mathrm{g}$ \\
\hline 4 day & $50.00 \mathrm{hi}$ & $53.50 \mathrm{i}$ & $60.50 \mathrm{~g}-\mathrm{k}$ & $44.50 \mathrm{fg}$ & $48.50 \mathrm{~g}$ & $51.40 \mathrm{jk}$ \\
\hline 6 day & $16.00 \mathrm{pq}$ & $45.50 \mathrm{j}$ & 30.50 no & $42.75 \mathrm{fgh}$ & $48.50 \mathrm{~g}$ & $36.65 n$ \\
\hline 8 day & 19.50 op & $44.00 \mathrm{j}$ & 27.50 no & $21.00 \mathrm{i}$ & $29.00 \mathrm{i}$ & $28.20 \mathrm{p}$ \\
\hline Mannitol $0.50 \mathrm{~mol} / 12$ day & $69.25 \mathrm{de}$ & 77.50 cde & $82.75 \mathrm{a}$ & $63.00 \mathrm{abc}$ & $69.25 \mathrm{bcd}$ & $72.35 \mathrm{~b}$ \\
\hline 4 day & $59.50 \mathrm{fg}$ & $81.50 \mathrm{bcd}$ & $68.00 \mathrm{e}-\mathrm{h}$ & $57.50 \mathrm{bcd}$ & $69.00 \mathrm{bcd}$ & $67.10 \mathrm{def}$ \\
\hline 6 day & $69.00 \mathrm{de}$ & 72.50 efg & $61.50 \mathrm{~g}-\mathrm{k}$ & $57.00 \mathrm{~cd}$ & $68.50 \mathrm{bcd}$ & 65.70 efg \\
\hline 8 day & $53.50 \mathrm{gh}$ & $71.00 \mathrm{e}-\mathrm{h}$ & $43.00 \mathrm{~m}$ & $57.00 \mathrm{~cd}$ & $50.00 \mathrm{~g}$ & $54.90 \mathrm{i}$ \\
\hline Mannitol $0.60 \mathrm{~mol} / 12$ day & $80.50 \mathrm{bc}$ & $86.50 \mathrm{ab}$ & $83.50 \mathrm{a}$ & $65.00 \mathrm{abc}$ & $71.00 \mathrm{abc}$ & $77.30 \mathrm{a}$ \\
\hline 4 day & $73.50 \mathrm{~cd}$ & $80.00 \mathrm{bcd}$ & $67.00 \mathrm{e}-\mathrm{i}$ & $62.00 \mathrm{abc}$ & $59.00 \mathrm{ef}$ & $68.30 \mathrm{cde}$ \\
\hline 6 day & $65.00 \mathrm{ef}$ & $40.00 \mathrm{j}$ & $60.50 \mathrm{~g}-\mathrm{k}$ & $57.00 \mathrm{~cd}$ & $57.50 \mathrm{f}$ & $62.00 \mathrm{~h}$ \\
\hline 8 day & $41.50 \mathrm{j}$ & $56.50 \mathrm{i}$ & $58.50 \mathrm{ijk}$ & $35.50 \mathrm{~h}$ & $58.50 \mathrm{ef}$ & $50.10 \mathrm{kl}$ \\
\hline LSD \%5 & 6.87 & 6.73 & 7.63 & 6.74 & 5.90 & \\
\hline Mean (LSD \%5: 1.17) & $49.11 \mathrm{e}^{* * *}$ & $66.17 \mathrm{a}$ & $58.77 \mathrm{c}$ & $51.91 \mathrm{~d}$ & $59.98 \mathrm{~b}$ & LSD \%5: 3.01 \\
\hline
\end{tabular}

***: Significantly important at $\mathrm{p}<0.001$ 


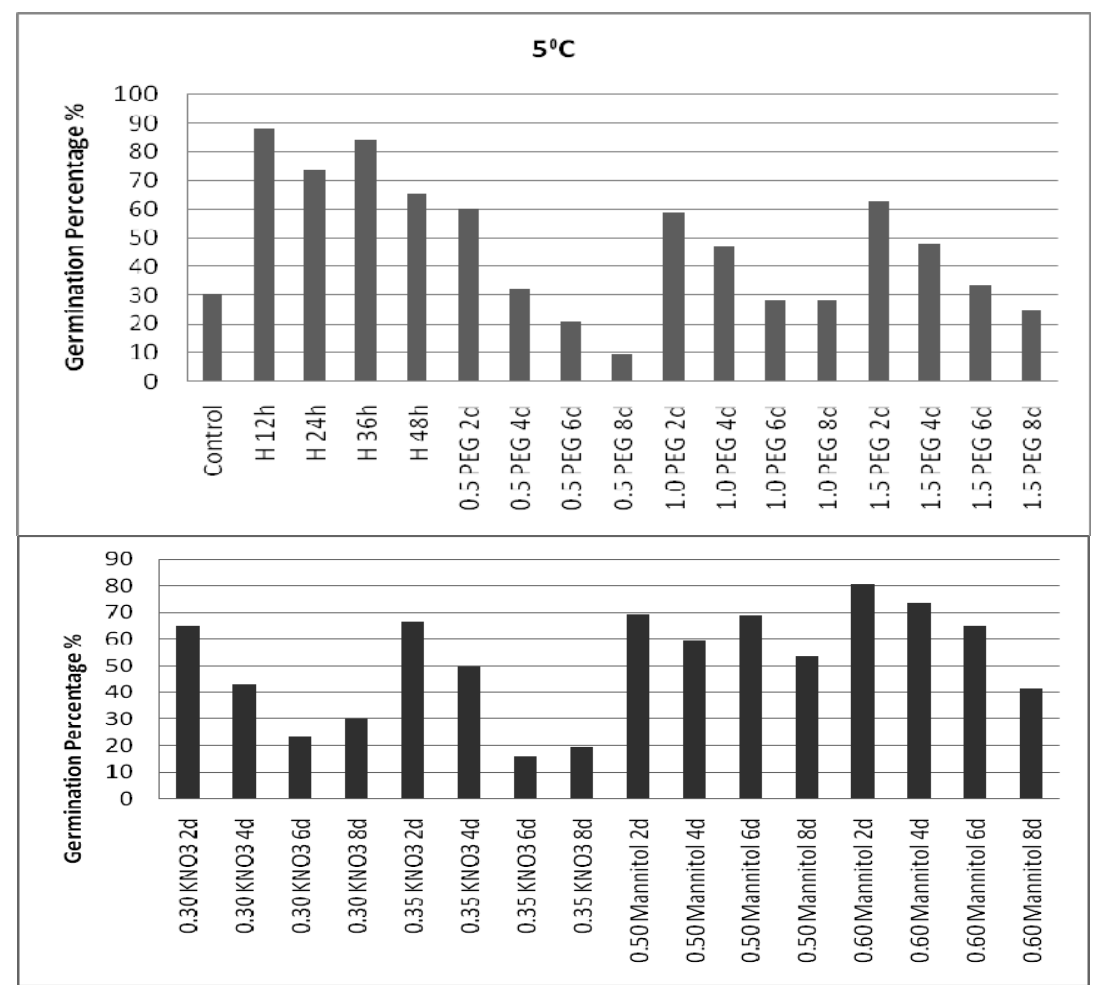

Figure 1. Effect of seed priming on germination percentage of parsley at $5^{\circ} \mathrm{C}$.

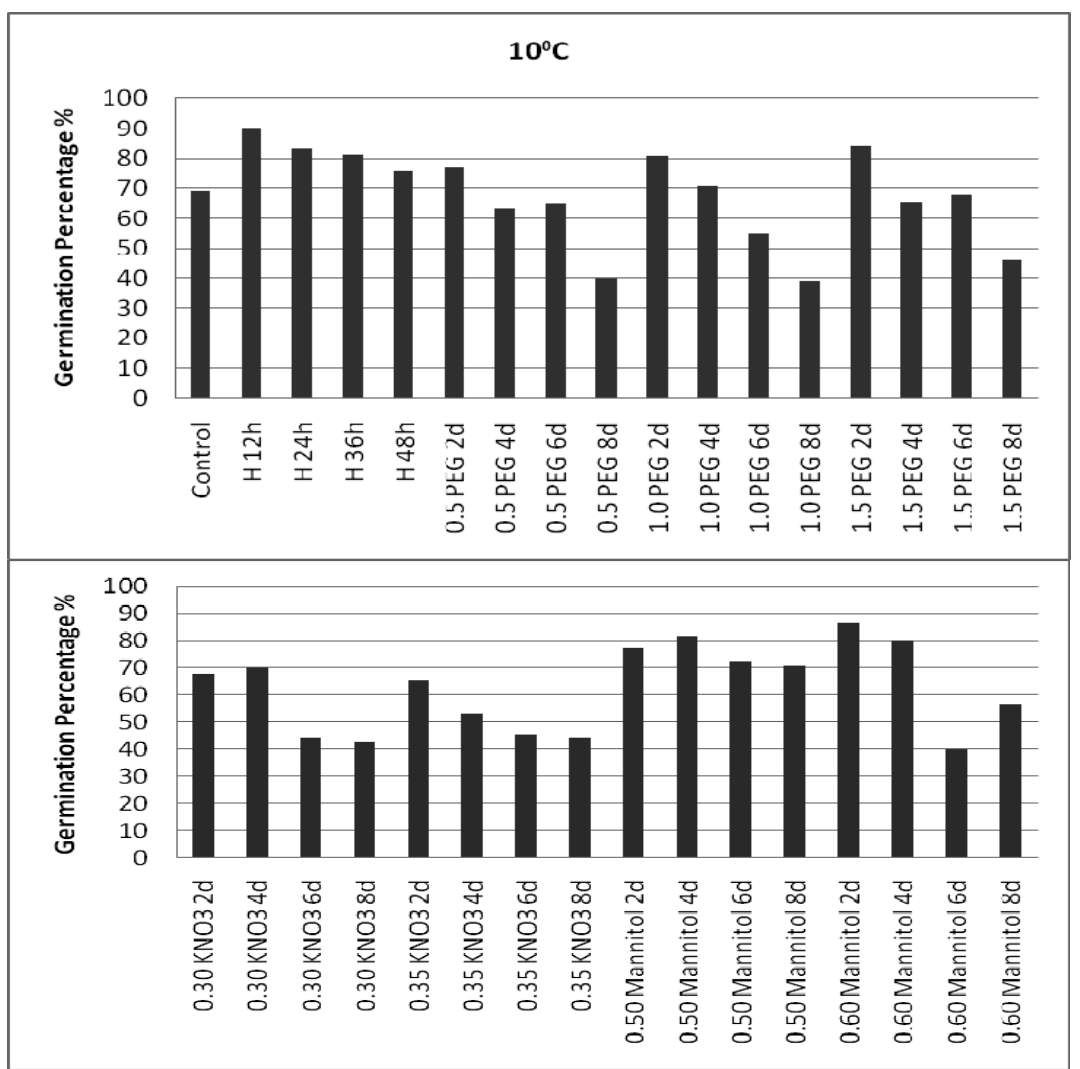

Figure 2. Effect of seed priming on germination percentage of parsley at $10^{\circ} \mathrm{C}$. 


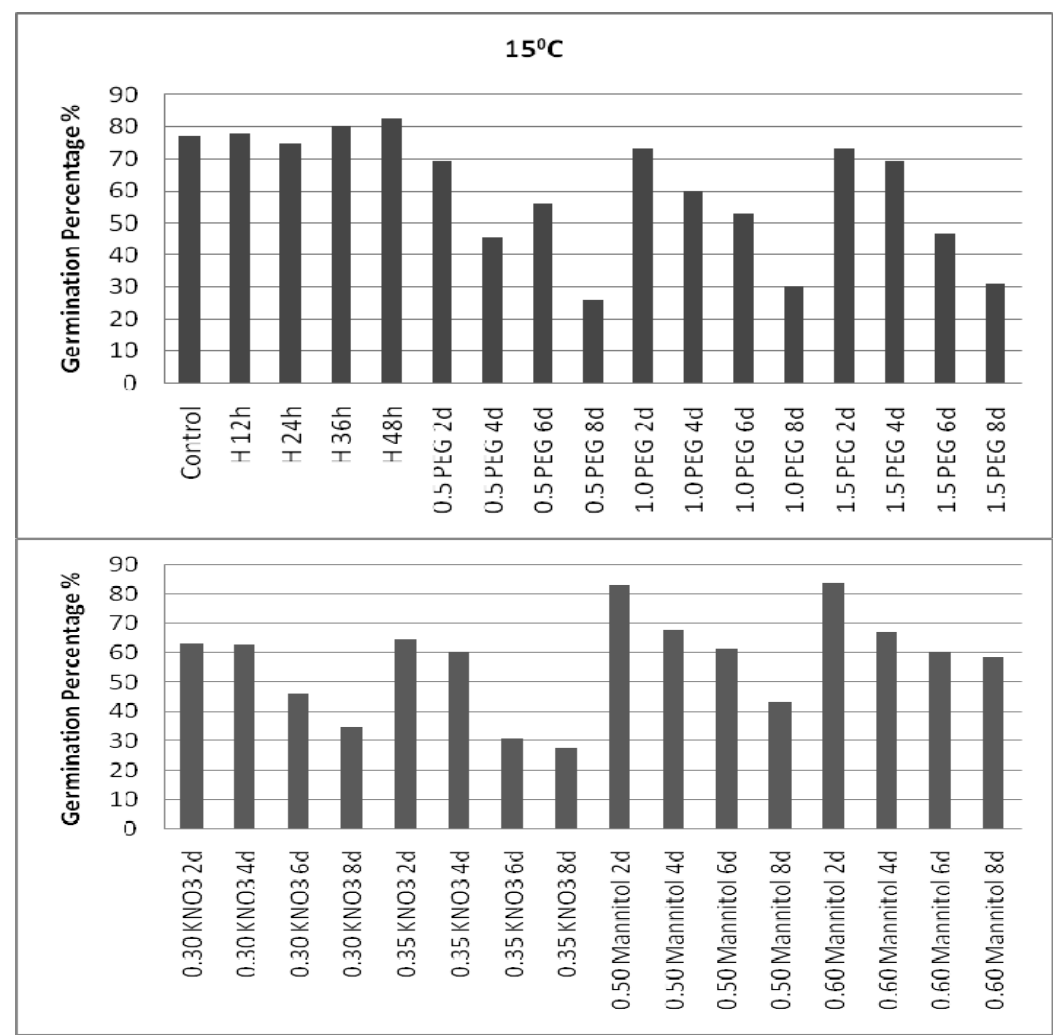

Figure 3. Effect of seed priming on germination percentage of parsley at $15^{\circ} \mathrm{C}$.

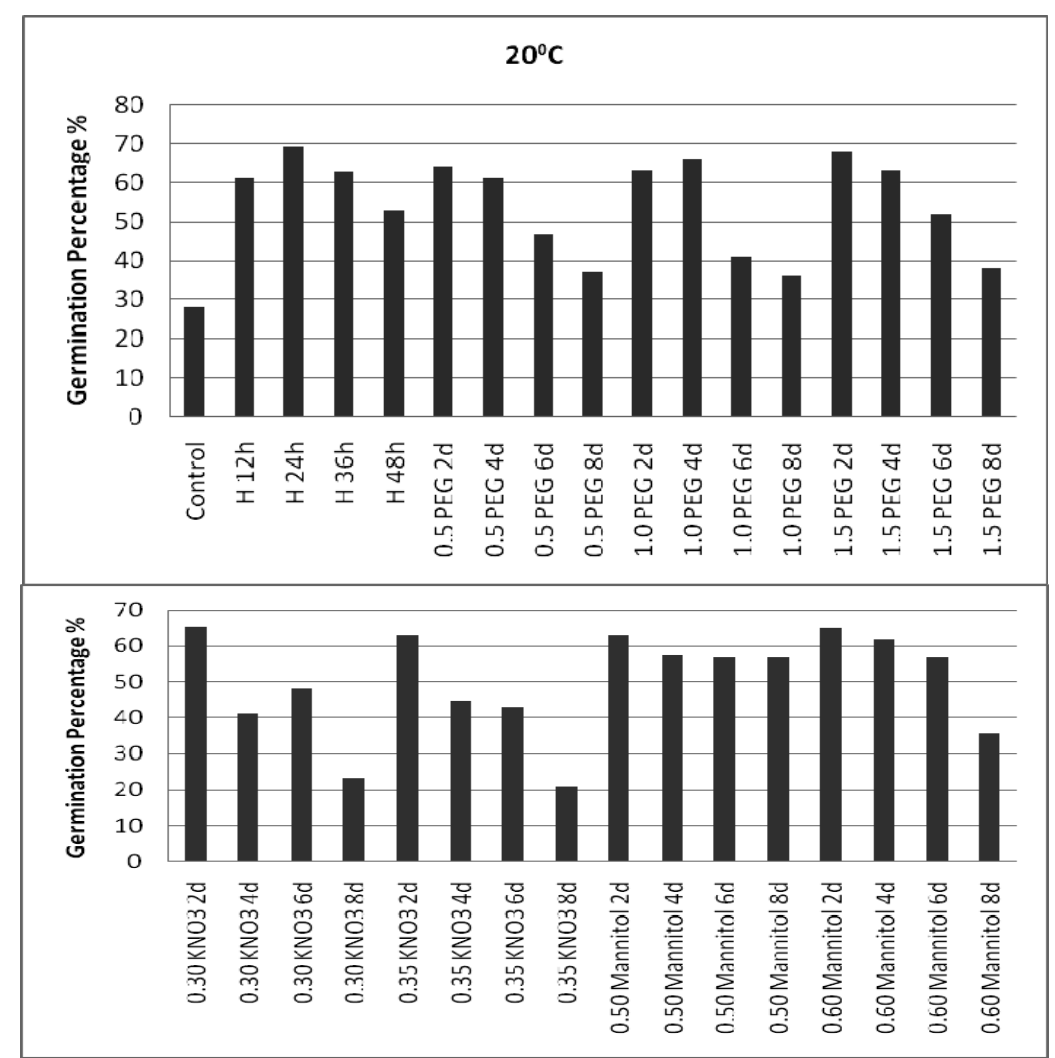

Figure 4. Effect of seed priming on germination percentage of parsley at $20^{\circ} \mathrm{C}$. 


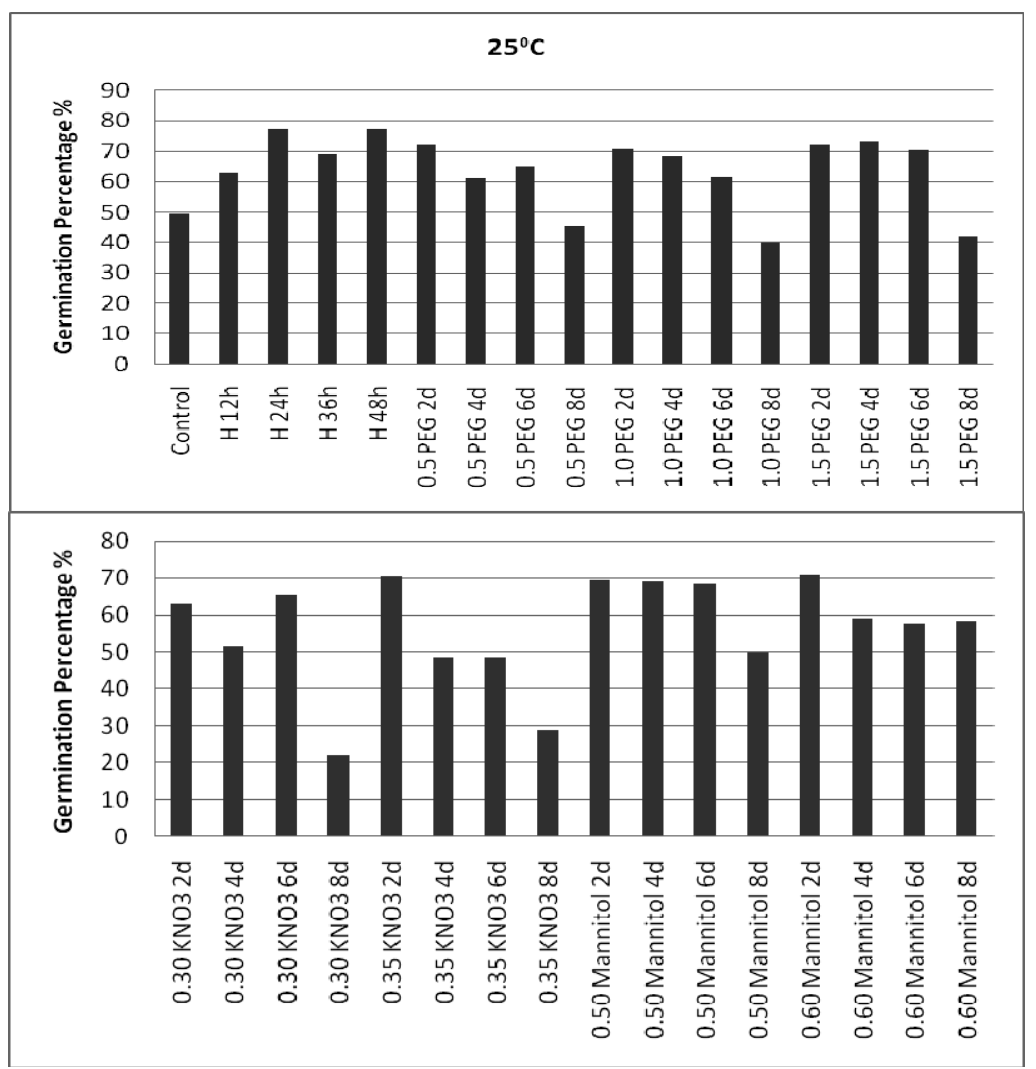

Figure 5. Effect of seed priming on germination percentage of parsley at $25^{\circ} \mathrm{C}$.

\section{DISCUSSION}

The findings presented on seed germination of parsley in this research showed similar results with different researches being made on priming treatment at different plant seeds so far. As matter of fact that, Zheng et al. [13] for canola, YeonOk et al. [14] for salvia, YeonOk et al. [15] for carrot, lettuce and onion, Nascimento [16] and Nascimento and Aragao [4] for muskmelon reported that priming treatments affected on seed germination at different temperatures in different plant species. Perezgarcia et al. [17] detected that the highest germination percentages for celery seeds were obtained from $15^{\circ} \mathrm{C}$ and $25 / 15^{\circ} \mathrm{C}$ (day-night temperatures). Nascimento [18] also observed that primed melon, watermelon, eggplant and tomato seeds had higher germination rate at low temperature degrees. In addition, Elkoca et al. [19] reported that osmopriming and hydropiriming treatments increased chickpea seed germination rates at different temperatures ranging from 5 to $32^{\circ} \mathrm{C}$.

When the treatments used in this study were evaluated, the highest germination percentage was observed in hydropriming and mannitol treatments as compared with PEG, $\mathrm{KNO}_{3}$ and the control. Hence, it could be said that PEG and $\mathrm{KNO}_{3}(2$ and 4 day) treatments were better than unprimed treatment in all of the temperature regimes. Our results are good to fit those of Olszewski et al. [20] who reported that osmotic priming $(-1.5$ or $-1.0 \mathrm{MPa}$ for 7,14 or 21 at $20 \mathrm{deg}$ C) increased parsley germination rates, but decreased germination percentage depending on treatments. Olszewski et al. [21] also found that when increasing priming duration $(-1,0 \mathrm{MPa}$ for 7, 14 or 21 at $20 \operatorname{deg}$ C), it quadratically increased parsley germination rate and additionally increased linearly seed moisture content. Pill and Kilian [22] reported that priming treatments (osmotically in polyethylene glycol or matrically in fine, exfoliated vermiculite at $-0.5 \mathrm{MPa}$ for 4 or 7 days at 20 or $30 \mathrm{deg} \mathrm{C}$ with 0 or 1 mM GA3) have stimulated and hastened parsley seed germination. Duman and Eşiyok [10] reported that germination percentage of carrot seed increased in using PEG $(81 \%)$ or $\mathrm{KH}_{2} \mathrm{PO}_{4}(79 \%)$ compared to control (75\%). Similarly, Duman [23] and Yildırım et al. [24] determined that PEG, $\mathrm{KNO}_{3}$ and $\mathrm{NaCl}$ treatments had significantly increased on germination percentage of onion seeds compared that of the control. Demir and Mavi [25] reported that the pepper seed germination was higher and sensivity index were lower in $\mathrm{NaCl}$ than in PEG treatments in both water potential and harvest. In the another research, they reported that the salt priming $\left(\mathrm{KNO}_{3}, 3 \%, 6\right.$ day, $\left.20^{\circ} \mathrm{C}\right)$ increased watermelon emergence and produce well-developed seedlings particularly in early spring sowings at low temperatures in greenhouse conditions [26]. Elkoca et al. [19] reported that 
hydropriming for $12 \mathrm{~h}$ or osmopriming with $-0.5 \mathrm{MPa}$ PEG for $24 \mathrm{~h}$ resulted in the highest seed germination of chickpea. Arin and Kiyak [27] stated that priming of tomato seeds (especially $\mathrm{KNO}_{3}$ ) improved emergence and seedling growth under stress (low temperature, drought and salinity) conditions. Osmopriming (PEG-6000) treatments had the best conditions for leek seeds in 7-10 days at $15^{\circ} \mathrm{C}$ and -15 bars [28]. Similarly, PEG solution $(-1.1$ and $-1.8 \mathrm{MPa})$ improved germination soybean seed compared to control [29]. And also Pazdera and Hosnedl [30] reported that the osmopriming was suitable method for lettuce seed germination. Sivritepe and Eriş [31] detected that priming treatments $(-0.25,-0.50$ and $-0.75 \mathrm{MPa}$ with PEG-8000, $10^{-3} \mathrm{M}$ and $10^{-4} \mathrm{M}$ with ABA and 2, 4 and 6 days with distilled water $\left.\left(\mathrm{H}_{2} \mathrm{O}\right)\right)$ at $16^{\circ} \mathrm{C}$ increased the germination percentage and decreased the mean germination time in pea seeds. Sadeghian and Yavari [32] reported that the highest concentration of mannitol decreased seedling growth and germination rates on sugar beet seed. Nascimento [16] suggested that salt solutions $(0.30 \mathrm{~mol} / \mathrm{L}$ or $0.35 \mathrm{~mol} / \mathrm{L}$ potassium nitrate $\mathrm{KNO}_{3} ; 0.30$ or $0.40 \mathrm{~mol} / \mathrm{L}$ potassium dihydrogen phosphate $\left(\mathrm{KH}_{2} \mathrm{PO}_{4}\right) ; 0.15$ or $0.20 \mathrm{~mol} / \mathrm{L}$ potassium nitrate +0.15 or $0.20 \mathrm{~mol} / \mathrm{L}$ potassium dihydrogen phosphate; 0.50 or $0.60 \mathrm{~mol} / \mathrm{L}$ mannitol; and 0.04 or $0.05 \mathrm{~mol} / \mathrm{L}$ polyethylene glycol/liter) had better germination rate on seeds of muskmelon. It was also reported that the best treatment to seed of muskmelon for germination and emergence at low temperature was $2.5 \% \mathrm{KNO}_{3}$ for $16 \mathrm{~h}$ in dark [33]. Demir et al. [34] reported that $\mathrm{GA}_{3}$ and $\mathrm{KNO}_{3}$ treatments influenced on eggplant seed germination and rate of germination respect comparing that of the control. In addition, Brocklehurst et al. [35] stated that PEG gave suitable results for different vegetable species such as onion, leek, and celery and $\mathrm{KH}_{2} \mathrm{PO}_{4}$ had effect of reducing in percentage germination and emergence in leek and celery. According to another research, $0.1 \mathrm{M} \mathrm{KNO}_{3}$ and $0.1 \mathrm{M} \mathrm{KH}_{2} \mathrm{PO}_{4}$ pre-storage treatments were the most effective for delaying viability loss due to ageing in onion seed [36]. Sivritepe et al. [37-39] indicated that priming of melon seeds with $\mathrm{NaCl}$ resulted in increased salt tolerance in seedling, total germination and mean germination time. Results of presented research were similar and confirmative to the mentioned studies above.

In conclusion, the effects of seed priming depend on the crop species. Seed priming is safe, effective and easily adopted by farmers. It also has the potential to benefit such farmers in many ways and hence, its importance is recognized by farmers as well as researchers. Priming increased the percentage of germination of parsley in this study. Therefore, parsley seed should be primed in order to perform better under unfavorable environmental conditions.

\section{REFERENCES}

[1] Chivasa, W., Harris, D., Chiduza, C., Nyamudeza, P. and Mashingaidze, A.B. (1998) Agronomic practices, major crops and farmer's perceptions of the importance of good stand establishment in Musikavanhu Communal Area, Zimbabwe. Journal of Applied Science in Southern Africa, 4(2), 108-125.

[2] Murungu, E.S., Chiduza, C., Nyamugafata, P., Clark, L.J. and Whalley, W.R. (2004) Effect of on-farm seed priming on emergence, growth and yield of cotton and Maize in a semi-arid area of Zimbabwe. Experimental Agriculture, 40(1), 23-36.

[3] Harris, D. (1996) The effects of manure, genotype, seed priming, depth and date of sowing on the emergence and early growth of Sorghum bicolor (L.) Moench in semi-arid Botswana. Soil and Tillage Research, 40(1-2), 73-88.

[4] Nascimento, W.M. and Aragao, F.A.S. (2004) Muskmelon seed priming in relation to seed vigor. Scientia Agricola, 61(1), 114 -117.

[5] Black, M. and Bawley, J.D. (2000) Seed technology and its biological basis. Sheffield Academic Press, Sheffield.

[6] Duman, İ. (2005) Olumsuz çevre koşullarında tohumların çimlenme ve çıkış performansı nasıl artırılabilir? Hasad Dergisi, 21(246), 72-78.

[7] Vural, H., Eşiyok, D. and Duman, İ. (2000) Kültür sebzeleri (sebze yetiştirme). Ege Üniversitesi Ziraat Fakültesi Bahçe Bitkileri Bölümü, Bornova-İzmir, 440.

[8] Günay, A. (2005) Sebze yetiştiriciliği cilt II. İzmir, 531.

[9] Cantliffe, D.J. (2003) Seed enhancement. ISHS Acta Horticulturae 607: IX International Symposium on Timing of Field Production in Vegetable Crops, Sao Paulo, 13 May 2003, 34(1).

[10] Duman, İ. and Eşiyok, D. (1998) Ekim öncesi PEG ve $\mathrm{KH}_{2} \mathrm{PO}_{4}$ uygulamalarının havuç tohumlarının çimlenme ve çıkış oranı ile verim üzerine etkileri. Turkish Journal of Agriculture and Forestry, 22, 445-449.

[11] Lee, J.M. (2004) Advances in seed treatments for horticultural crops. Chronica Horticulturae, 44(2), 11-20.

[12] Barlow, E.W.R. and Haigh, A.M. (1987) Effect of seed priming on the emergence, growth and yield of UC 82B tomatoes in the field. ISHS Acta Horticultrae 200: II. International Symposium on Processing Tomatoes, XXII IHC, Davis, 1 March 1987, 22(1).

[13] Zheng, G.H., Wilen, R.W., Slinkard, A.E. and Gusta, L.V. (1994) Enhancement of canola seed-germination and seedling emergence at low temperature by priming. Crop Science, 34(6), 1589-1593.

[14] YeonOk, J., SeongMo, K. and JeoungLai, C. (2000) Priming conditions to improve germination of salvia (Salvia splendens F.) seeds. Korean Journal of Horticultural Science and Technology, 18(2), 98-102.

[15] YeonOk, J., JongCheol, K. and JeoungLai, C. (2000) Effect of priming duration and temperature on the germinability of carrot, lettuce, onion, and welsh onion seeds. Korean Journal of Horticultural Science and Technology, 18(3), 327-333.

[16] Nascimento, W.M. (2003) Muskmelon seed germination and seedling development in response to seed priming. Scientia Agricola, 60(1), 71-75. 
[17] Perezgarcia, F., Pita, J.M., Gonzalezbenito, M.E. and Iriondo, J.M. (1995) Effects of light, temperature and seed priming on germination of celery seeds (Apium graveolens L.). Seed Science and Technology, 23(2), 377-383.

[18] Nascimento, W.M. (2005) Vegetable seed priming to improve germination at low temperature. Horticultura Brasileria, 23(2), 211-214.

[19] Elkoca, E., Haliloğlu, K., Eşitken, A. and Ercişli, S. (2007) Hydro and osmopriming improve chickpea germination. Acta Agriculturae Scandinavica Section B Soil and Plant Science, 57(3), 193-200.

[20] Olszweski, M.W., Evans, T.A., Gregory, N.F. and Pill, W.G. (2005) Enhanced germination of primed mericarps of parsley (Petroselinum crispum Mill. Nyman ex A.W.Hill) limited by Alternaria alternate proliferation. Journal of Horticultural Science and Biotechnology, 80(4), 427-432.

[21] Olszewski, M., Pill, W., Pizzolato, T.D. and Pesek, J. (2005) Priming duration influences anatomy and germination responses of parsley mericarps. Journal of the American Society for Horticultural Science, 130(5), 754758.

[22] Pill, W.G. and Kilian, E.A. (2000) Germination and emergence of parsley in response to osmotic or matric seed priming and treatment with gibberellin. Horticultural Science, 35(5), 907-909.

[23] Duman, İ. (2002) Soğan (Allium cepa L.) tohumlarının çimlenmesini iyileştirici farklı osmotik uygulama yöntemlerinin karşılaştırılması. Ege Üniversitesi Ziraat Fakültesi Dergisi, 39(2), 1-8.

[24] Yıldırım, E., Dursun, A., Güvenç, İ. and Kumlay, A.M. (2002) Effects of different salt, biostumulant and temperature levels on seed germination of some vegetable species. Acta Agrobotanica, 55(2), 75-80.

[25] Demir, İ. and Mavi, K. (2008) Effect of salt and osmotic stresses on the germination of pepper seeds of different maturation stages. Brazilian Archives of Biology and Technology, 51(5), 897-902.

[26] Demir, İ. and Mavi, K. (2004) The effect of priming on seedling emergence of differentially matured watermelon (Citrullus lanatus (Thunb.) Matsum and Nakai) seeds. Scientia Horticulturae, 102(4), 467-473.

[27] Arin, L. and Kiyak, Y. (2003) The effects of pre-sowing treatments on emergence and seedling growth of tomato seed (Lycopersicon esculentum Mill.) under several stress conditions. Pakistan Journal of Biological Sciences, 6(11), 990-994.

[28] Corbineau, F., Picard, M.A. and Come, D. (1994) Germinability of leek seeds and its improvement by osmo- priming. ISHS Acta Horticulture 371: VII International Symposium on Timing Field Production of Vegetables, Skierniewice, 1 July 1994, 57(1).

[29] Khalil, S.K., Mexal, J.G. and Murray, L.W. (2001) Germination of soybean primed in aerated solution of polyethylene glycol (8000). Online Journal of Biological Sciences, 1(3), 105-107.

[30] Pazdera, J. and Hosnedl, V. (2002) Effect of hydration treatments on seed parameters of different lettuce (Lactuca sativa L.) seed lots. Horticultural Science, 29(1), 12-16.

[31] Sivritepe, H.Ö. and Eris, A. (2000) The effects of poststorage priming treatments on viability and repair of genetic damage in pea seeds. ISHS: XXV International Horticultural Congress, Part 7: Quality of Horticultural Products, 517, 143-149.

[32] Sadeghian, S.Y. and Yavari, N. (2004) Effect of waterdeficit stress on germination and early seedling growth in sugar beet. Journal of Agronomy and Crop Science, 190(2), 138-144.

[33] Dhillon, N.P.S. (1995) Seed priming of male sterile muskmelon (Cucumis melo L.) for low temperature germination. Seed Science and Technology, 23(3), 881884.

[34] Demir, İ., Ellialtığlu, S. and Tipirdamaz, R. (1993) The effect of different priming treatments on reparability of aged eggplant seeds. ISHS: International Symposium on Agrotechnics and Storage of Vegetable and Ornamental Seeds, Bari, 14-16 June 1993, 362, 205-212.

[35] Brocklehurst, P.A., Dearman, J. and Drew, R.L.K. (1987) Recent developments in osmotic treatment of vegetable seeds. ISHS Acta Horticulturae 215: Seed Research in Horticulture, 30(1).

[36] İlbi, H. and Eser, B. (2004) The effects of seed treatments on ageing in onion seed. Ege Üniversitesi Ziraat Fakültesi Dergisi, 41(1), 39-48.

[37] Sivritepe, H.Ö., Eris, A. and Sivritepe, N. (1999) The effect of $\mathrm{NaCl}$ priming on salt tolerance in melon seedling. ISTA: I International Symposium on Cucurbits, Adana, 1 May 1999, 492, 77-84.

[38] Sivritepe, H.Ö., Eris, A. and Sivritepe, N. (1999) The effect of priming treatments on salt tolerance in melon seeds. ISTA: I International Symposium on Cucurbits, Adana, 1 May 1999, 492, 287-295.

[39] Sivritepe, H.Ö., Sivritepe, N., Eriş, A. and Turhan, E. (2005) The effects of $\mathrm{NaCl}$ pre-treatments on salt tolerance of melon grown under long-term salinity. Science Horticulturae, 106(4), 568-581. 